Care: Jurnal Ilmiah Ilmu Kesehatan Vol .7, No.2, 2019, hal 22-31

Tersedia online di https://jurnal.unitri.ac.id/index.php/care

ISSN $2527-8487$ (online)

ISSN 2089-4503 (cetak)

\title{
PERILAKU KURANG GERAK (SEDENTARY BEHAVIOUR) DENGAN PERKEMBANGAN PSIKOSOSIAL ANAK PRA SEKOLAH
}

\author{
Laviana Nita Ludyanti \\ Program Studi S1 Keperawatan STIKES Karya Husada Kediri \\ E-mail : lavianakh@gmail.com
}

\begin{abstract}
The development of science and technology, creates various kinds of conveniences that cause an increase in sedentary behavior. This also has an impact on the development of pre-school age children, one of which is psychosocial development. This study aims to determine the relationship between sedentary behaviour and psychosocial development in pre-school children. The design of this study is correlational with a cross sectional approach. The population in this study were mothers of pre-school age children at ABA II Kindergarten, with a sample of 35 people using purposive sampling techniques. Its collected with quessionaire. Statistical analysis using a Spearman Rank Test with $a=0.05$. The results showed that most children had psychosocial development in the not appropriate category of $71 \%$. While the lack of motion behavior in the heavy category was $77 \%$. The results showed that there was a significant relationship between sedentary behavior and psychosocial development in pre-school children with results $(r=0.457 ; \varrho=0,00<a=$ 0.05). Parents should involve children in activities outside the bome and conduct management of children's activities according to their growth as an effort to improve psychosocial development in pre-school children.
\end{abstract}

Keywords : Sedentary Behaviour; Psikososial Development; Pra School.

\begin{abstract}
ABSTRAK
Perkembangan iptek, menciptakan berbagai macam kemudahan yang menyebabkan adanya peningkatan perilaku kurang gerak (Sedentary Behaviour) yang berdampak terhadap perkembangan anak usia pra sekolah, salah satunya adalah perkembangan psikososial. Penelitian ini bertujuan untuk mengetahui adanya hubungan antara perilaku kurang gerak dengan perkembangan psikososial pada anak pra sekolah. Desain penelitian ini adalah korelasional dengan pendekatan cross sectional. Populasi dalam penelitian ini adalah ibu dari anak usia pra sekolah di TK ABA II, sampel 35 orang dengan teknik purpossive Sampling. Data diambil dengan menggunakan kuesioner. Analisis statistik menggunakan Uji Spearman Rank dengan $\alpha=0,05$. Hasil penelitian menunjukkan bahwa sebagian besar anak memiliki perkembangan psikososial dalam kategori tidak sesuai sebesar $71 \%$. Sedangkan perilaku kurang gerak dalam kategori berat sebesar 77\%. Hasil uji analisa data menunjukkan bahwa ada hubungan yang signifikan antara perilaku kurang gerak dengan perkembangan psikososial anak pra sekolah dengan hasil $(r=0.457 ; \varrho=0,000<\alpha=0,05)$. Salah satu upaya yang dapat diterapkan orang tua dalam peningkatan perkembangan psikososial anak pra sekolah adalah dengan melibatkan anak dalam aktivitas di luar rumah dan melakukan manajemen terhadap kegiatan anak sesuai tumbuh kembangnya.
\end{abstract}

Kata Kunci : Perilaku Kurang Gerak; Perkembangan Psikososial; Pra Sekolah.

Cara mengutip: Ludyanti, L. Nita. (2019). Perilaku Kurang Gerak (Sedentary Behaviour) Dengan Perkembangan Psikososial Anak Pra Sekolah. Care:Jurnal Ilmiah Ilmu Kesehatan, 7(2), 22-31 


\section{PENDAHULUAN}

Perkembangan ilmu pengetahuan dan teknologi memberikan dampak yang signifikan terhadap gaya dan pola hidup masyarakat. Peralatan yang serba canggih dan serba instan, mendorong seseorang lebih cenderung untuk malas bergerak dan kurang aktivitas fisik yang menimbulkan peningkatan sedentary behaviour pada anak yang menghasilkan pola hidup santai (Tremblay, et al., 2011). Hasil penelitian pada anak usia sekolah menunjukan bahwa responden pada hari weekend rata-rata melakukan sedentary behaviour meningkat menjadi 4.98 jam/hari dari hari weekday yang memiliki rata-rata $3.55 \mathrm{jam} /$ hari. Peningkatan penggunaan waktu sedentary saat hari weekend disebabkan oleh peluang waktu untuk melakukan sedentary behaviour lebih banyak dibanding saat weekday. Perilaku sedentary pada anak sendiri dipengaruhi oleh beberapa faktor seperti status ekonomi, pendidikan orang tua dan lingkungan (Setyoadi, Rini, \& Novitasari, 2015).

Data populasi dari Amerika Utara, Inggris dan Eropa menunjukkan bahwa anak-anak dan remaja menghabiskan sebagian besar dari hari mereka untuk menetap (kurang bergerak). Di Amerika Serikat, misalnya, 6 hingga 11 dan 12 hingga 15 tahun di Survei Kesehatan dan Gizi Nasional 2003-2004 menghabiskan sekitar 40\% (6 jam) dan >
$50 \%$ (7,5 jam) dari mereka bangun berjamjam. Selain orang dewasa yang berusia $\geq 60$ tahun, remaja perempuan berusia 16 hingga 19 tahun adalah kelompok usia paling tua berikutnya $(60 \%$ dari jam bangun; 8 jam)(Cliff, 2016).

Hasil penelitian lain menunjukkan dari 86 remaja yang terlibat, $100,0 \%$ memiliki aktivitas tingkat sedang dan berat yang cukup, 30,2\% memiliki kecukupan aktivitas olah raga tingkat berat, dan 17,4\% memiliki kecukupan aktivitas olahraga tingkat sedang. Pada perilaku sedentari, 89,5\% memiliki kebiasaan menonton tv, 100\% memiliki kebiasaan bekerja dengan komputer atau laptop, 26,7\% memiliki kebiasaan bermain video game, 100,0\% memiliki kebiasaan duduk-duduk, 48,8\% remaja memiliki lama waktu tidur yang buruk (Cahyani, 2012). Hasil penelitian (Valerie C, 2015) menunjukkan gaya hidup menetap juga terjadi di awal tahapan tumbuh kembang yaitu usia $0-5$ tahun. Anak-anak di tahun-tahun awal menghabiskan $73 \% \quad-84 \%$ dari waktu bangun mereka sedang tidak aktif. Sebagian besar anak-anak di tahun-tahun awal menghabiskan lebih dari 1 jam per hari untuk waktu layar (screen time) dan melakukan kegiatan berbasis layar sebelum usia 2 tahun (Le Blanc, 2012). 
Care: Jurnal Ilmiah Ilmu Kesehatan Vol .7, No.2, 2019, hal 22-31

Sedentary behaviour menimbulkan efek negatif terhadap kesehatan, sehingga menjadikannya sebagai isu penting dalam kesehatan masyarakat (Ochoa, et al., 2013). Sedentary behaviour merupakan sekelompok perilaku yang terjadi saat duduk atau berbaring yang membutuhkan pengeluaran energi yang sangat rendah, seperti duduk atau berbaring sambil menonton televisi, bermain game elektronik, membaca, dan lain sebagainya (Arundhana, Hadi, \& Julia, 2013). Dampak yang dapat ditimbulkan dari sedentary behaviour diantaranya adalah gangguan kardiometabolik, gangguan respirasi (asma), gangguan psikososial (cemas, depresi, harga diri rendah) dan termasuk juga gangguan pertumbuhan dan perkembangan (Cliff, 2016). Dari hasil studi pendahuluan, dari 10 wali murid di TK ABA menyatakan bahwa anaknya sering mengalami kurang konsentrasi saat belajar, kurang mandiri, sering minta bantuan ke orang sekitar, dan emosi.

Pertumbuhan dan perkembangan adalah satu unit kesatuan yang menggambarkan sejumlah perubahan yang terjadi sepanjang siklus hidup individu. Proses tersebut bersifat dinamis dan menitikberatkan pada hubungan antara dimensi pertumbuhan, perkembangan, maturasi dan diferensiasi (Wong, 2004). Pada masa pra sekolah merupakan masa yang sangat peka terhadap lingkungan, masa sangat pendek dan tidak dapat diulang lagi sehingga masa ini disebut sebagai masa keemasan (golden period), jendela kesempatan (window of opportunity), dan juga sebagai masa kritis (critical period) (RI, 2015). Kegagalan pada satu tahapan tumbuh kembang maka akan mempengaruhi tahap tumbuh kembang berikutnya, salah satunya pada perkembangan psikososial.

Pada anak yang lebih banyak mengalami sedentary behaiour, akan lebih banyak waktu digunakan untuk bermain sendiri, dan kurang bergerak dan berinteraksi dengan lingkungan luar. Hal ini tentunya juga akan berpengaruh terhadap perilaku anak baik secara individu maupun ke orang lain. Anak akan cenderung kurang mandiri, lebih emosi, agresif, sulit berkomunikasi dan bergaul dengan teman lain, perilaku manja, perilaku merusak dan sulit berkonsentrasi. Berdasarkan uraian di atas, maka penulis ingin mengetahui hubungan perilaku kurang gerak (Sedentary Behaviour) dengan perkembangan psikososial anak usia pra sekolah.

\section{METODE PENELITIAN}

Penelitian dilakukan di TK ABA II menggunakan desain korelasional dengan pendekatan cross sectional. Populasi pada penelitian ini adalah anak usia pra sekolah di TK ABA II Pare Kediri sebanyak 65 
siswa. Sampel dalam penelitian ini adalah ibu dari anak usia pra sekolah (4-6 tahun) di TK ABA II sebanyak 35 responden. Teknik sampling yang digunakan adalah Non Probability Sampling tipe Purpossive Sampling. Penelitian dilakukan untuk mengetahui hubungan perilaku kurang gerak (sedentary behaviour) terhadap perkembangan psikososial anak usia pra sekolah. Data dikumpulkan menggunakan kuesioner. Analisa data dilakukan menggunakan Uji Spearman Rank dengan $\alpha=0,05$.

\section{HASIL}

Tabel 1. Data Umum Karakteristik Responden

$\begin{array}{llcc} & & \text { Jumlah } & (\%) \\ \text { Usia Ibu } & \text { 20-30 tahun } & 10 & 28,6 \\ & \text { 31-40 tahun } & 23 & 65,7 \\ \text { Pendidikan } & \text { SD } 40 \text { tahun } & 2 & 5,7 \\ \text { Ibu } & \text { SMP } & 0 & 0 \\ & \text { SMA } & 0 & 0 \\ & \text { PT } & 21 & 60 \\ \text { Jenis } & \text { Laki-laki } & 14 & 40 \\ \text { Kelamin } & \text { Perempuan } & 21 & 60 \\ \text { Anak } & & 14 & 40 \\ \text { Usia Anak } & 4 \text { tahun } & 17 & 49 \\ & 5 \text { tahun } & 12 & 34 \\ \text { Jumlah } & \text { T tahun } & 6 & 17 \\ \text { saudara } & \text { Tidak punya } & 4 & 11,5 \\ \text { kandung } & 2 & 16 & 46 \\ & 3 & 11 & 31 \\ & \text { 3 } & 4 & 11,5\end{array}$

Berdasarkan tabel di atas diketahui bahwa sebagian besar responden berumur 31 - 40 tahun yaitu sejumlah 18 responden $(65,7 \%)$. Sebagian besar responden berpendidikan SMA sebanyak 21 responden $(60 \%)$. Responden anak dengan jenis kelamin laki - laki sebanyak 21 responden $(60 \%)$. Usia anak berusia 4 tahun sebanyak 17 responden (49\%). Jumlah saudara kandung yang dipunyai oleh responden sebanyak 16 responden (46\%) memiliki saudara kandung sebanyak satu orang.

Tabel. 2. Perilaku Kurang Gerak (Sedentary Behaviour) pada anak usia Pra Sekolah

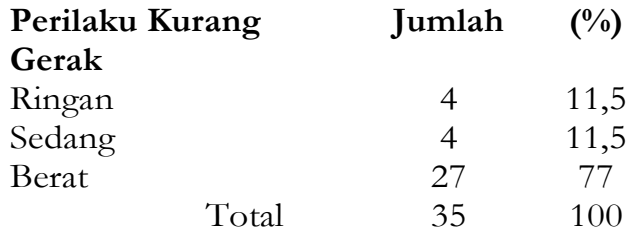

Berdasarkan tabel dapat diketahui bahwa sebagian kecil responden memiliki perilaku kurang gerak dalam kategori berat yaitu sebanyak 27 responden (77\%) dan sebagian besar responden memiliki perilaku kurang gerak dalam kategori ringan dan sedang masing-masing sebanyak 4 responden $(11,5 \%)$.

Tabel 3. Perkembangan Psikososial Anak Usia Pra Sekolah Perkembangan Jumlah psikososial anak pra sekolah

\begin{tabular}{lcr} 
Sesuai & 0 & 0 \\
Kurang sesuai & 10 & 29 \\
Tidak sesuai & 25 & 71 \\
\multicolumn{1}{c}{ Total } & 35 & 100
\end{tabular}

Berdasarkan tabel dapat diketahui bahwa anak yang memiliki perkembangan psikososial tidak sesuai yaitu sejumlah 25 responden $(71 \%)$.

Berdasarkan hasil analisis menggunakan uji Spearman Rho diketahui bahwa nilai $p$-value $=0.000$ 
Care: Jurnal Ilmiah Ilmu Kesehatan Vol .7, No.2, 2019, hal 22-31

pada taraf signifikan $(\alpha)=0.05$, maka $\mathrm{H} 1$ diterima yang berati ada hubungan cukup. Hal ini dapat disimpulkan bahwa ada hubungan perilaku kurang gerak (sedentary behaviour) dengan perkembangan psikososial anak usia pra sekolah. Sedangkan nilai koefisien korelasi $(r)=0.457$ bernilai positif yang berarti semakin berat perilaku kurang gerak maka tingkat perkembangan anak pra sekolah lebih cenderung ke kategori perkembangan tidak sesuai.

\section{PEMBAHASAN}

Berdasarkan hasil penelitian, didapatkan data bahwa sebagian besar responden memiliki perilaku kurang gerak dalam kategori berat. Sedangkan sebagian kecil memiliki perilaku kurang gerak dalam kategori sedang dan ringan. Perilaku kurang gerak yang dilakukan oleh anak usia pra sekolah meliputi kegiatan menonton TV lebih dari satu jam, melakukan kegiatan yang lebih banyak duduk, kurang melakukan aktivitas fisik yang berat serta malas melakukan kegiatan.

Perilaku kurang gerak merupakan perilaku bangun yang terkait dengan pengeluaran energi $\leq 1,5$ MET dan posisi duduk atau berbaring dan dianggap terpisah dan berbeda dari kurangnya aktivitas fisik intensitas sedang hingga kuat (tidak memenuhi aktivitas fisik yang sesuai)
(Sedentary Behavior Research Network 2012;

Tremblay et al., 2011).

Aktivitas yang dilakukan anak dengan lebih lama menonton televisi, membaca buku, bercerita, bermain handphone, meminta bantuan dalam melakukan pekerjaan, serta aktivitas di luar rumah yang kurang, menyebabkan pengeluaran energi tubuhnya juga kurang sehingga hal ini lebih cenderung meningkatkan resiko perilaku kurang gerak.

Perilaku kurang gerak dapat disebabkan oleh berbagai hal, diantaranya adalah jenis pekerjaan/ aktivitas, hobi/ kesenangan, fasilitas/ kemudahan, kebiasaan serta kurang berolahraga (Le Blanc, 2012). Anak yang memiliki hobi membaca akan cenderung untuk melakukan perilaku kurang gerak, sedangkan anak yang memilik hobi bermain di luar rumah, berolahraga maupun aktivitas di luar rumah lainnya maka perilaku kurang gerak cenderung lebih ringan. Fasilitas yang ada di lingkungan sekitar anak juga sangat berpengaruh terhadap perilaku kurang gerak. Anak akan lebih memilih untuk memanfaatkan fasilitas yang ada untuk mendapatkan kemudahan. Termasuk diantaranya adanya jumlah saudara kandung maupun banyaknya anggota dalam keluarga. Berdasarkan penelitian, 
sebagian besar anak memiliki saudara kandung. Hanya 11,5\% responden yang tidak memiliki saudara kandung. Hal ini juga dapat memicu anak untuk lebih banyak melakukan perilaku kurang gerak karena adanya saudara yang dapat membantunya dalam memenuhi kebutuhannya. Jika anggota dalam keluarga lebih banyak, anak lebih cenderung kurang gerak, karena adanya bantuan dari banyak orang untuk melakukan aktivitasnya seharihari.

Anak usia pra sekolah yang mengalami kurang gerak akan berpengaruh terhadap perkembangan psikosoaialnya. Perkembangan psikososial pada anak usia pra sekolah di TK ABA II, sebagian besar $71 \%$ masuk dalam kategori perkembangan psikososialnya tidak sesuai, sedangkan 29\% dalam kategori perkembangan kurang sesuai. Menurut (Hurlock, 2011), anak akan berusaha untuk mengenal dirinya sendiri, belajar menyesuaikan dengan teman sebaya, mengembangkan peran sosial sesuai dengan gendernya, mengembangkan sikap sosial terhadap kelompok atau lembaga serta mencapai kebebasan pribadi.

Pada usia pra sekolah, menurut Erikson perkembangan psikososial anak dalam kategori inisiatif dan rasa bersalah.
Perkembangan inisiatif diperoleh dengan cara mengkaji lingkungannya melalui kemampuan indranya. Anak mengembangkan keinginannya dengan cara mengeksplorasi terhadap hal-hal yang ada di sekelilingnya. Perasaan bersalah akan timbul bila anak tidak mampu berprestasi sehingga anak merasa tidak puas atas perkembangan yang dicapai.

Berdasarkan penelitian sebagian besar responden berjenis kelamin laki-laki sebesar 60\%. Sesuai dengan karakteristik perkembangannya, pada usia ini anak akan lebih cenderung untuk mengembangkan peran sosial dan adaptasi dengan teman sebaya melalui kegiatan-kegiatan yang ada di luar rumah dan lebih menantang. Apabila anak mengalami kurang gerak, maka perkembangan psikososial anak lebih banyak dalam kategori tidak sesuai.

Kemampuan anak dalam menyelesaikan masalah akan diperoleh jika konsep diri anak positif, karena anak mulai berkhayal dan kreatif serta meniru peran-peran di sekelilingnya. Anak mulai berinisiatif melakukan sesuatu dan merasa bersalah bila tindakannya berdampak negatif (Keliat, B. A., 2009). Anak yang memiliki perilaku kurang gerak dalam kategori sedang maupun berat, kreativitasnya menjadi terbatas, anak cenderung 
Care: Jurnal Ilmiah Ilmu Kesehatan Vol .7, No.2, 2019, hal 22-31

emosional, cemas dan menjadi minder.

Oleh sebab itu perkembangan psikososial mereka akan masuk dalam kategori tidak sesuai.

Ada berbagai faktor yang menyebabkan seorang anak perkembangan psikososialnya tidak sesuai. Hal tersebut diantaranya adalah tingkat pendidikan ibu, usia ibu, jenis kelamin dan jumlah saudara kandung. Berdasarkan penelitian ada 60\% ibu yang memiliki pendidikan SMA dan $40 \%$ tingkat pendidikannnya adalah Perguruan Tinggi. Menurut (Soetjiningsih, 2012) beberapa faktor pendukung dalam perkembangan anak, yaitu terpenuhinya kebutuhan anak tersebut, peran aktif orang tua, lingkungan yang merangsang semua aspek perkembangan anak, peran aktif anak dan pendidikan orang tua. Ibu yang memiliki pendidikan lebih tinggi, akan cenderung lebih mudah mendapatkan informasi dan mengaplikasikannya dalam menstimulasi perkembangan anaknya. Ibu juga mampu untuk melakukan manajemen waktu dan kegiatan yang diterapkan pada anaknya. Hal ini tentunya dapat mengurangi timbulnya perilaku kurang gerak pada anak.

Dalam penelitian ini sebagian besar Ibu dengan usia 31-40 tahun, yaitu sebesar
65,7\%. Hal ini menunjukkan bahwa pada usia ini merupakan usia produktif. Pada usia ini ibu lebih aktif untuk terus memantau perkembangan dan kegiatan anaknya. Akan tetapi ada banyak hal yang dapat mempengaruhi ibu untuk tidak dapat memantau secara terus menerus. Dari responden juga menyebutkan bahwa mereka lebih merasa tenang ketika anak diam dan lebih banyak melakukan kegiatan di dalam rumah. Oleh sebab itu, hal ini justru memicu peningkatan perilaku kurang gerak pada anak.

Perilaku kurang gerak berkaitan dengan kesehatan dan perkembangan pada anak usia 5-12 tahun. Pada usia ini, anak memiliki karakteristik lebih dekat dengan orang tua, anak telah menguasai perasaan untuk berpikir mandiri, dengan dukungan orang tua dalam imajinasi dan aktivitas, anak berusaha menguasai perasaan inisiatif, anak juga mengembangkan perasaan bersalah ketika orang tua membuat anak merasa bahwa imajinasi dan kreativitasnya tidak dapat diterima. Ansietas dan ketakutan terjadi ketika pemikiran dan aktivitas anak tidak sesuai dengan harapan orang tua (Hurlock, 2011).

Salah satu faktor yang berpengaruh terhadap perkembangan psikososial anak adalah bertambahnya usia anak. 
Menurut (Tanaka, 2013), bertambahnya usia pada anak laki-laki dan perempuan akan meningkatkan skor skala perkembangan psikososial pada anak tersebut. Pada penelitian ini, hampir setengah responden berusia 4 tahun sebesar 49\%, yang berusia 5 tahun sebesar 34\% sedangkan usia 6 tahun sebesar 17\%. Semakin meningkat usia anak maka perasaan inisiatif dan imajinatif anak akan lebih meningkat, begitu juga sebaliknya. Pada responden, anak lebih banyak berusia 4 tahun, yang pada usia tersebut perasaan inisiatif dan imajinatif belum terlalu muncul pada anak.

Berdasarkan data hasil penelitian diketahui ada hubungan antara perilaku kurang gerak (sedentary behaviour) dengan perkembangan psikososial pada anak pra sekolah di TK ABA II Pare, Kediri. Hal ini dibuktikan dengan hasil uji statistik menggunakan Spearman Rho yang menunjukkan nilai koefisien korelasi $\mathrm{r}=0,457$ yang menyatakan bahwa tingkat hubungannya cukup dan semakin berat perilaku kurang gerak pada anak, maka perkembangan psikososialnya menunjukkan tidak sesuai, dengan $\mathrm{p}$ value $<0,05$.

Dampak dari perilaku kurang gerak dapat mencakup secara fisik maupun psikologis seperti obesitas, penyakit kardio- metabolik (misalnya insulin dan kolesterol), osteoporosis, diabetes tipe dua, gangguan sistem pernapasan (misalnya Asma), kesehatan psikososial (misalnya kecemasan, harga diri, perilaku dan kualitas hidup), kognisi dan prestasi akademik (misalnya perhatian dan prestasi sekolah), keterampilan motorik kasar dan berbagai kanker (Cliff, 2016).

Dari hasil penelitian yang menunjukkan perilaku kurang gerak dalam kategori berat sebesar 77\%. Hal ini akan menimbulkan dampak bagi anak, baik jangka panjang maupun jangka pendek. Dari segi perkembangan psikososial, anak lebih banyak dalam kategori perkembangan tidak sesuai.

Menurut (Klossner, N.J; Hatfield, 2010) pada usia pra sekolah merupakan fase magical thinking, yang membuat mereka sedikit kesulitan membedakan antara imajinasi dan realita. Imajinasi mereka membuat anak pra sekolah menjadi pendengar yang setia, lebih menyukai bercerita, bermain sederhana dan menonton televisi. Hal ini tentunya justru akan meningkatkan perilaku kurang gerak (sedentary behaviour) pada anak.

Upaya untuk melibatkan anak dengan teman sebayanya, dapat mengoptimalkan 
Care: Jurnal Ilmiah Ilmu Kesehatan Vol .7, No.2, 2019, hal 22-31

perkembangan psikososial pada anak pra sekolah. Anak yang lebih banyak melakukan perilaku kurang gerak, kurang dapat berinteraksi dengan teman sebayanya secara baik, sehingga hal ini menyebabkan perkembangan psikososial anak lebih banyak yang tidak sesuai. Oleh sebab itu perlu adanya tindakan pencegahan pada anak.

Pencegahan perilaku kurang gerak dapat dilakukan oleh orang tua dengan melibatkan orang dan lingkungan sekitar misalnya dengan melakukan manajemen terhadap kegiatan anak, melibatkan anak dalam aktivitas fisik yang sesuai dengan tumbuh kembangnya serta membatasi penggunaan/ aktivitas yang berbasis layar seperti televisi, komputer maupun smartphone.

\section{KESIMPULAN}

1) Sebagian besar anak usia pra sekolah memiliki Perilaku kurang gerak (Sedentary) Behaviour).

2) Sebagian besar anak usia Pra Sekolah memiliki perkembangan psikososial yang tidak sesuai.

3) Ada hubungan antara perilaku kurang gerak (Sedentary Behaviour) dengan perkembangan psikososial pada anak usia pra sekolah.

\section{UCAPAN TERIMAKASIH}

Terima kasih kepada Prodi S1
Keperawatan STIKES Karya Husada Kediri yang telah memberikan bantuan dana dalam pelaksanaan penelitian ini dan seluruh responden dan semua pihak yang telah membantu pelaksanaan penelitian.

\section{REFERENSI}

Arundhana, A. I., Hadi, H., \& Julia, M. (2013). Perilaku Sedentari Sebagai Faktor Risiko Kejadian Obesitas Pada Anak Sekolah Dasar Di Kota Yogyakarta Dan Kabupaten Bantul. Jurnal Giri Dan Dietetik Indonesia, 1(2), 71-80.

Cahyani, A. E. (2012). Gambaran Aktivitas Fisik, Perilaku Sedentary dan Status Kelebihan Berat Badan Pada Mahaisina Usia 18-20 Tabun Sebagai Faktor Risiko Sindroma Metabolik (Studi Kasus Pada Mahasiswa Fkm Undip). Universitas Diponegoro Semarang.

Cliff, et al. (2016). Objectively measured sedentary behaviour and health and development in children and adolescents: systematic review and meta-analysis. Pediatric Obesity/ Behaviour. World Obesity, 17, 330-344.

Hurlock, E. . (2011). Psikologi Perkembangan. Jakarta: Erlangga.

Keliat, B. A., \& A. (2009). Model Praktek Keperawatan Prefesional Jiwa. Jakarta: EGC.

Klossner, N.J; Hatfield, N. . (2010). Maternity and Pediatric Nursing. Second Edition. Lippincott: William and Wilkins.

Le Blanc, et al. (2012). Systematic review of sedentary behaviour and health indicators in the early years 9aged 0-4 years). Appl. Physiol. Nutr. Metab, 37, 753-772.

Ochoa, M., Moreno, A., Martinez, A., and Marti, A. (2013). Predictor Factors for Childhood Obesity in a Spanish Case Control Study. Nutrition Journal, 23, 379-384. Retrieved from http://www.ncbi.nlm.nih.gov/pubme 
$\mathrm{d} / 17408922$

RI, D. K. (2015). Profil Kesehatan Indonesia 2015. Jakarta: Departemen Kesehatan RI.

Setyoadi; Rini, Ika Setyo; Novitasari, T. (2015). Hubungan Penggunaan Waktu Perilaku Kurang Gerak (Sedentary Behaviour) Dengan Obesitas Pada Anak Usia 9-11 Tahun Di Sd Negeri Beji 02 Kabupaten Tulungagung. Jurnal Ilmu Keperawatan, 3(2).

Soetjiningsih. (2012). Tumbuh Kembang Anak. Jakarta: EGC.

Tanaka, A. (2013). Assesment of The Psycosocial Development of Children Attending Nursery School in Karen Refugee Camp in Thailand. Springer Science Journal.
Tremblay, M. S., Leblanc, A. G., Janssen, I., Kho, M. E., Hicks, A., Murumets, K., Colley, R. C., and Duggan, M. (2011). Canadian Sedentary Behaviour Guidelines for Children and Youth. Appl Physiol Nutr Metab, 36(1), 59-64. Retrieved from http://www.csep.ca/CMFiles/Guidel ines/SBGuidelinesChildandYouth_E. pdf

Valerie,C, et all. (2015). Systematic Review of Sedentary Behavior and Cognitive Development in Early Childhood. Preventive Medicine.

Wong. (2004). Keperawatan Pediatrik. Jakarta: EGC. 